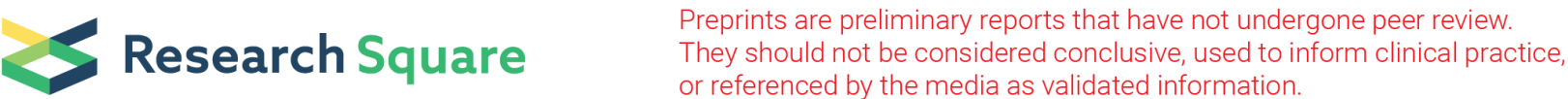

\section{Land Use Land Cover Changes and its Implication on the conservation of Re-introduced Kihansi Spay Toads (Nectophrynoides asperginis) in Kihansi Gorge-Tanzania}

Atuhombye Sigala ( $\square$ atusigala28@gmail.com )

The University of Dodoma

Kelvin Ngongolo

The University of Dodoma College of Natural Sciences and Mathematics

Naza Mmbaga

The University of Dodoma College of Natural Sciences and Mathematics

\section{Research}

Keywords: Land use, land cover, wild extinction, re-introduction, Kihansi spray toads

Posted Date: October 18th, 2021

DOl: https://doi.org/10.21203/rs.3.rs-961588/v1

License: (c) (1) This work is licensed under a Creative Commons Attribution 4.0 International License.

Read Full License 


\section{Abstract \\ Background}

Land use land cover change (LULCC) is a global threat to biodiversity conservation. Endemic species such as Kihansi spray toads (KST) are prone to extinction due to LULCC. This study assessed the LULCC of the Kihansi catchment (KC), a potential habitat for the KST and adjacent areas. Remote sensing (RS), geographical information system (GIS) and 156 questionnaires administered to three surrounding villages namely: Mgugwe, Udagaji and Ukami were used to assess the LULCC forms in the study area. Landsat imagery and ground truthing, were used to classify and monitor LULCC for 25 years from 1995 to 2020 .

\section{Results}

Settlements and agricultural land increased by $26.23 \%$ and $3.7 \%$ respectively. On the other hand, forested land decreased by a rate of $10-20 \%$ per year. Across respondents a significant increase $(p=0.041)$ of the population was reported which contributed to settlement expansion. LULC of KC and adjacent areas were observed to change over the years that anticipate threatening the reintroduced KST and its habitat.

\section{Conclusions}

This study provides baseline information for land use planning in $\mathrm{KC}$ and adjacent areas that consider the sustainable conservation of re-introduced KST while improving the livelihood of the adjacent local communities.

\subsection{Introduction}

Biodiversity hot spot areas host global potential for the conservation of wildlife species particularly those that are endemic and critically endangered like the KST (Lindenmayer, 2019). Land use land cover changes (LULCC) contribute to the extreme loss and extinction of endemic, rare and endangered biodiversity species such as the Kihansi spray toads (KST). Human activities such as infrastructure development and agriculture support LULCC and threaten species through habitat loss, fragmentation, and destruction (Mmbaga et al., 2017; Franco-Belussi, et al., 2020). It has also been reported that human induced LULCC triggers ecological changes that lead to a decrease in biodiversity and increased species loss (Franco-Belussi, et al., 2020; Rija et al., 2011).

In Tanzania, there are many anthropogenic factors such as cultivation, lumbering and infrastructure construction which could threaten biodiversity resources such as the Kihansi spray toad (Franco-Belussi, et al., 2020; Niesenbaum, 2019). Other studies have shown that, LULCC promotes changes in biotic communities beyond species composition (Franco-Belussi, et al., 2020; Rija et al., 2011). During its 
discovery (before dam construction in 1996) the KST was estimated at 20,000) individuals (Nahonyo, 2019). Due to habitat dryness influenced by water diversion after dam construction the number of toads decreased (Rija, et al., 2011). Artificial sprinklers were made to mimic the natural spray leading to an increase in number of toads in 2001 (Nahonyo, 2019; Rija, et al., 2011). A sudden decrease in toad numbers occurred again between 2003 and 2004; hence there was no heard or sighted toad in their habitat. This led to their extinction in the wild declaration in 2009 (Nahonyo, 2019). It is believed that, Kihansi dam construction resulted in alteration of biodiversity habitats thus resulting in the extinction of the KST in the wild (Rija et al., 2011). The habitat has been restored and the KST has been re-introduced. However, little is known about LULCC taking place in the area which could have impacts on the survival of KST apart from dam construction which is also important in the alteration of biodiversity. In this case, understanding the extent to which LULCC is taking place in the Kihansi ecosystem is essential for the sustainable conservation of biodiversity including the re-introduced KST.

In this study we focused on assessing the extent to which LULCC has taken place in the Kihansi ecosystem for the last 25 years from 1995 to 2020 . Additionally, the opinions of local communities on LULCC were inquired from the respondents adjacent to the Kihansi Catchment habitat for the KST. This study is essential for the sustainable conservation of the re-introduced KST and wildlife species.

\subsection{Materials And Methods}

\subsection{Study area}

The study was conducted in KC and adjacent areas (Udagaji, Mgugwe and Ukami villages), referred to as the Kihansi area. It is located in the Kilombero and Mufindi Districts of south central Tanzania $\left(07815^{\circ}-\right.$ $08845^{\circ} \mathrm{S}, 35800^{\circ}-37800^{\circ} \mathrm{E}$ ). Kihansi catchment covers about $0.9 \mathrm{~km}^{2}$ and rises from $300 \mathrm{~m}$ to around $2,500 \mathrm{~m}$ above sea level (asl) in the east and north-south respectively. The area contains a closed canopy of wood and rain forests with mixed tree species which including Mninga (Pterocarpus angolensis), Mpangapanga (Millettia stuhlmannii), Msekeseke (Bobgunnia madagascariensis), Pamosa (Afzelia quanzensis), Msufi (Bombax rhodognaphalon), and Mtondo/Mtondoro (Julbernardia globiflora), Mhongo, and other diverse endemic and endangered flora and fauna (Kibbassa, 2014). Crop production and livestock keeping are the major economic activities in this area and covering approximately $85 \%$ and 10 $\%$ respectively (Kibbassa, 2014). The study area varies in weather and elevation leading to the cultivation of different crops, fruits and vegetables. Maize (Zea mays), cassava (Manihot esculenta), sweet potatoes (Ipomoea batatas), bananas (Musa sp), oranges (Citrus sinensis), and guava (Psidium guajava) are grown in both areas (Kibbassa, 2014). Wheat (Triticum aestivum), finger millet (Eleusine coracana) and round potatoes are crops grown in highlands (Kibbassa, 2014) whereas paddy (Oryza sativa), sorghum (Sorghum bicolor), coconut (Cocos nucifera), cashew nuts (Anacardium occidentale), palm-oil and sugarcane (Saccharum officinarum) are crops grown in lowlands (Kibbassa, 2014; Nwilene et al., 2013; Yudha et al., 2019).

\subsection{Image acquisition, processing and analysis}


The area under the study were identified, demarcated and different categories of LULC were classified using Google earth Pro as suggested by Ngongolo, Estes, Hudson, \& Gwakisa (2019). The area was monitored for the last 25 years from 1995-2020. Landsat 5 Thematic Mapper (TM) and Landsat 8 Operational Land Imager (OLI) imagery were used to analyze land cover change of the years 1995, 2004 and 2020, respectively. The aim of choosing these years was to compare the LULC of the KC and its adjacent areas before dam construction (1995), after dam construction (2004) and after restoration and reintroduction of the toads (2020). The Kihansi catchment area extends within a single Landsat path and row. High resolution satellite imagery ( $30 \mathrm{~m}$ spatial resolution) was used to download images from the US Geological Survey (USGS) Earth Explorer (http://earthexplorer.usgs.gov).

Table 1

Satellite image descriptions

(Source: http://earthexplorer.usgs.gov).

\begin{tabular}{|c|c|c|c|c|c|}
\hline \multicolumn{6}{|c|}{ Description } \\
\hline Year & Path & Raw & Space craft ID & Sensor ID & Date acquired \\
\hline 1995 & 168 & 66 & Land Sat 5 & TM & 23 June 1995 \\
\hline 2004 & 168 & 66 & Land Sat 5 & TM & 17 July 2004 \\
\hline 2020 & 168 & 66 & Land Sat 8 & OLI TIRS & 14 August 2020 \\
\hline
\end{tabular}

The images were selected based on season (dry season) as previously suggested by (Mmbaga et al., 2017) because during the dry season, it was possible to identify forested land and the remaining bare lands were considered agricultural lands. All images (1995, 2004 and 2020) were obtained within the same time of the year (ranging between June 23 and August 14) (Table 1). Shape files for study site boundaries were obtained from The National Bureau of Statistics (NBS) available at (https://openmicrodata.worldpress.com). Satellite images of different years were imported into ArcGIS (version 10.3) for processing and analysis. The geographic coordinate system was defined as the World Geographical System (WGS) 1984 and projected to the Universal Transverse Mercator (UTM) Zone 37S prior to analysis. Image processing and analysis included image clipping and composite bands formation. In this study, natural colour bands were used. Three Landsat images were classified by using the maximum likelihood function, which is the most common decision rule among the supervised classification (Mmbaga et al., 2017). It is also considered to give very accurate results because each pixel is assigned to the class to which it has a highest probability of belonging (Mmbaga et al., 2017) Visual interpretation and digital image classification were then combined using GIS functions.

Three land use classes defined in the study area were: (1) agricultural land (seasonal cultivated lands, bush lands, bare lands open areas, grasslands, and livestock grazing); (2) forested land (3) Settlement (any type of buildings). Training sites were determined and signature files were created to be used in the classifications by using ArcGIS (version 10.3). After that, the classified images were compared with ground truthing (field visit) that was achieved with the assistance from Kihansi management team 
members to validate the collected information and modified accordingly. Additionally, to improve the accuracy on the past images of the years 1995, 2004, and 2020 interviews with local people were conducted. To improve and analyze the data at a better quality scale, the LULC classification and analysis were done across the three villages: Udagaji, Mgugwe and Ukami.

\subsection{Data collected on Land use land covers changes through questionnaire survey from local communities adjacent the Kihansi area.}

The interviews involved 156 respondents from the three study villages (Udagaji, Mgugwe and Ukami). Extensive field observations and interviews were conducted by administering a structured questionnaire to respondents aged 45 years and above, who had lived in the respective location for at least 25 years from the age of self-awareness (15years). The information captured through the questionnaire was as follows: awareness of respondents on land use types of $\mathrm{KC}$ and adjacent areas in relation to KST conservation within the range of 1995 to 2021. In addition, the socio-economic activities of local communities and the trends of different land use types over the past 25 years were captured. In addition, reasons that could promote changes in land use and cover were addressed in the questionnaire survey. Furthermore, the dynamic changes in terms of the human population, livestock, agricultural land, water bodies and forested land for the past 25 years were investigated during the questionnaire survey. The variation of opinions obtained from respondents across the three study villages was analyzed using the Kruskal Wallis statistical test.

\subsection{Results}

\subsection{Land use land cover (LULC) types and changes in Kihansi area}

In 1995 forested land covered the largest area 33921.83 acres $(70.80 \%)$ followed by agricultural land 10520.15 acres $(21.95 \%)$ and settlement 3475.14 acres (7.25\%). In 2004 forested land decreased to 25969.70 acres $(54.20 \%)$, a very small increase in agricultural land to 10619.80 acres $(22.16 \%)$ while settlement increased to 11327.68 acres (23.64\%). In 2020 there was a continuous decrease in forested land to 19583.17 acres (40.87\%), a slight increase in agricultural land to 12289.52 acres $(25.65 \%)$ and an increase in settlement to 16044.43 acres (33.48\%) (Table 2, Figure 2). There was a consistent decrease in forested land from $70.80 \%$ coverage in 1995 to $54.20 \%$ in 2004 and $40.87 \%$ in 2020 . Settlements had increased by about $26.23 \%$ over the past 25 years (between 1995 and 2020), while agricultural land has increased by about $3.7 \%$ suggesting that the area that was previously forested land was converted into settlements and agricultural land (Table 2). 
Table 2

Land use land cover (LULC) types in acre and \% in Kihansi area from the years 1995 to 2020.

\begin{tabular}{|lllllll|}
\hline & 1995 & & 2004 & & 2020 \\
\\
\hline Land use types & Area (Acre) & $\%$ & Area (Acre) & $\%$ & Area (Acre) & $\%$ \\
\hline Forest & 33921.83 & 70.80 & 25969.70 & 54.20 & 19583.17 & 40.87 \\
\hline Agricultural land & 10520.15 & 21.95 & 10619.80 & 22.16 & 12289.52 & 25.65 \\
\hline Settlement & 3475.14 & 7.25 & 11327.68 & 23.64 & 16044.43 & 33.48 \\
\hline Total & $\mathbf{4 7 9 1 7 . 1 2}$ & 100 & 47917.12 & 100 & 47917.12 & 100 \\
\hline
\end{tabular}

\subsection{LULC changes over monitored time.}

LULC types of Kihansi area have changed over time. Between 1995 and 2020 settlement has mostly increased than any other LULC type by $26.23 \%$, agricultural land has increased by $3.7 \%$ while forested land had strongly decreased by $29.93 \%$. However the change varied among time intervals, for instance between 1995 and 2004 forested land decreased by 16.6\% while, agricultural land and settlement increased by $0.21 \%$ and $16.39 \%$ respectively (Table 3 ).

Table 3

Changes in land use land cover in acre and \% in Kihansi area.

\begin{tabular}{|c|c|c|c|c|c|c|c|}
\hline Year & $1995-200$ & & 2004-202 & & $1995-202 C$ & & \\
\hline LULC type & Acre & $\%$ & Acre & $\%$ & Acre & $\%$ & $\mathrm{P}$ \\
\hline Forested land & 7952.13 & 16.6 & 6386.53 & 13.33 & 14338.66 & 29.93 & \multirow[t]{3}{*}{0.03} \\
\hline Agricultural land & -99.65 & -0.21 & -1669.72 & -3.49 & -1769.37 & -3.7 & \\
\hline Settlement & -7852.54 & -16.39 & -4716.75 & -9.84 & -12569.29 & -26.23 & \\
\hline
\end{tabular}

\subsection{Perception of respondents on the trends of LULC changes in Kihansi and area}

Settlement areas showed a significant $(P=0.04)$ increase. Of the 156 respondents $82.69 \%(n=129)$ reported an increase, 7.69\% ( $n=12)$ did not change and 9.62\% $(n=15)$ did not know. In the case of livestock $63.46 \%(n=99)$ reported an increase, $17.31 \%(n=27)$ decreased, $7.69 \%(n=12)$ had no change and $11.54 \%(n=18)$ did not know. Regarding cultivation land, $69.23 \%(n=108)$ of the respondents reported an increase, $11.54 \%(n=18)$ decreased, $9.62 \%(n=15)$ no change, and regarding water bodies, $63.46 \%(n=$ 99) reported a decrease, $7.69 \%(n=12)$ no change and $28.85 \%(n=45)$ did not know. Furthermore, $50 \%$ $(n=78)$ of the respondents reported a decrease in forests while, $32.69 \%(n=51)$ and $17.31 \%(n=27)$ reported an increase and not known respectively. 
Table 4

Responses of local communities' adjacent Kihansi catchment on Land use land cover changes for years

\begin{tabular}{|c|c|c|c|c|c|c|}
\hline \multirow[t]{2}{*}{ sn } & \multirow[t]{2}{*}{ Variable } & \multirow[t]{2}{*}{ Classification } & \multirow{2}{*}{$\begin{array}{l}\text { Udagaji } \\
\%(n=61)\end{array}$} & \multirow{2}{*}{$\begin{array}{l}\text { Ukami } \\
\%(n=48)\end{array}$} & Mgugwe & \multirow[t]{2}{*}{$\mathbf{P}$} \\
\hline & & & & & $\%(n=47)$ & \\
\hline \multirow[t]{4}{*}{1} & \multirow[t]{4}{*}{ Livestock } & Increase & 85.24 & 12.5 & 87.23 & \multirow[t]{4}{*}{0.264} \\
\hline & & Decrease & 9.84 & 31.25 & 12.77 & \\
\hline & & No change & 4.92 & 18.75 & 0 & \\
\hline & & Don't know & 0 & 37.5 & 0 & \\
\hline \multirow[t]{4}{*}{2} & \multirow[t]{4}{*}{ Forested land } & Increase & 40.98 & 37.5 & 0 & \multirow[t]{4}{*}{0.136} \\
\hline & & Decrease & 54.10 & 6.25 & 100 & \\
\hline & & No change & 0 & 0 & 0 & \\
\hline & & Don't know & 4.92 & 56.25 & 0 & \\
\hline \multirow[t]{4}{*}{3} & \multirow[t]{4}{*}{ Water bodies } & Increase & 0 & 0 & 0 & \multirow[t]{4}{*}{0.134} \\
\hline & & Decrease & 80.32 & 6.25 & 100 & \\
\hline & & No change & 9.84 & 12.5 & 0 & \\
\hline & & Don't know & 9.84 & 60.42 & 0 & \\
\hline \multirow[t]{4}{*}{4} & \multirow[t]{4}{*}{ Agricultural land } & Increase & 90.16 & 12.5 & 100 & \multirow[t]{4}{*}{0.247} \\
\hline & & Decrease & 4.92 & 37.5 & 0 & \\
\hline & & No change & 4.92 & 18.75 & 0 & \\
\hline & & Don't know & 0 & 31.25 & 0 & \\
\hline \multirow[t]{4}{*}{5} & \multirow[t]{4}{*}{ Human population } & Increase & 100 & 43.75 & 100 & \multirow[t]{4}{*}{0.041} \\
\hline & & Decrease & 0 & 0 & 0 & \\
\hline & & No change & 0 & 25 & 0 & \\
\hline & & Don't know & 0 & 31.25 & 0 & \\
\hline
\end{tabular}

\subsection{Opinion of local communities' adjacent Kihansi catchment on reasons for Land use land covers changes}

About 156 respondents pointed out the following as reasons for livestock increase: birth $20.16 \%$, immigration $37.5 \%$, pasture availability $31.45 \%$, human population increase $2.42 \%$, and drafting animals $8.47 \%$. The reasons for cultivated land increase were as follows: forest cleared to farms $43.01 \%$, wetland converted to farms $29.02 \%$, and grassland converted to farms $24.87 \%$. The reasons for population 
increase were fertile soils $25.30 \%$, immigration $43.78 \%$, birth $20.08 \%$, social services $8.43 \%$ and food availability $2.41 \%$. The reasons for forests decrease or increase were; cleared for farms $48.30 \%$, grassland $12.24 \%$, settlement $4.10 \%$, lumbering $6.12 \%$, and farms converted to forest plantations $29.25 \%$. The reasons for water bodies decrease as listed by respondents were; cultivation in wetland $41.61 \%$, human population increase $24.16 \%$, destruction of water catchments and sources $34.23 \%$.

Since 2010 to date there are strong efforts to restore the habitat and re-introduce the KST in their habitat. About 3370 individuals have been re-introduced since June 2012 to Apr 2021 (source: KCF). The trend shows increasing number of re-introduced toads. About 579, 573, 700, and 1518 individuals were reintroduced in 2012, 2018, 2019 and 2020 respectively (source: KCF). Apart from an increased number of re-introduced toads, forested land is continuously being converted to other land cover types (settlement and agricultural land). This projects conservation challenges on the re-introduced toads, thereby making an alert to conservationists to call for conservation assistance from communities adjacent KC.

\subsection{Discussion}

\subsection{Land use land cover (LULC) types and changes in Kihansi Catchment area}

Land use land cover changes in $\mathrm{KC}$ as revealed by landsat imagery showed a rapid decrease in forested land to other land cover forms ( $70.80 \%$ in 1995 to 40.87 in 2020) while increasing settlement and agricultural lands. A high percentage of forested land was converted to settlements and farms because the increased human population resulted in an increase in settlement area from $7.25 \%$ in 1995 to $33.48 \%$ in 2020 and farms for agriculture. This gives an alert to the continuous demand for more land for settlement and agriculture that will threaten endemic species found in the KC area including the KST. A study by Yudha, et al., (2019) in Indonesia revealed that, wildlife species including toads are threatened when the intact land is rapidly converted into human settlements and agriculture. The Kihansi catchment is surrounded by villages with local communities that have direct or indirect attachment to biodiversity. In addition, villagers surrounding the Kihansi catchment are undertaking various socio-economic activities such as cultivation, lumbering and infrastructure building. These activities destroy biodiversity including natural vegetation which leads to bare land cover, and loss of endemic, rare and endangered species including the KST (Kibbassa, 2014; Vandvik et al., 2014; Yudha, et al., 2019).

\subsection{Responses of respondents on the trends of LULCC in Kihansi area}

The respondents reported an increase in agricultural/cultivated land in all three study villages. Forested land was reported to decrease in udagaji and Mgugwe villages while increasing in Ukami villages. Furthermore, livestock and human populations have been reported to increase in all villages. An increase in cultivated land and reduction of forested land was due to increase in the human population and livestock which were geared by birth and immigration. Other findings have shown that, human and livestock population increase when there is high births and immigration rate. Births and immigration are 
influenced by availability of pasture, fertile soils food and good socio-services (health, education, roads, railway, water, electricity) (Mmbaga, et al., 2017; Thet, 2014).

Increases in human and livestock populations influences land cover change through deforestation, lumbering, pole cutting, grazing areas and the need for settlement areas (Karraker, et al., 2018). Different studies have shown that an increase in human population influences land cover changes which affect biodiversity conservation through habitat destruction (Karraker, et al., 2018; Mmbaga, et al., 2017). For instance the study by Karraker, et al., (2018) in Southeast Asian forests showed that agriculture is the major land use which converts forested land to other cover types leading to habitat loss. In addition, a study conducted in Indonesia showed that human settlement and paddy fields were the land use which changed the land cover of virgin land hence leading to decreased amphibian species diversity (Yudha et al., 2019).

\subsection{Implication on the conservation of KST}

It is known from elsewhere that, land use land cover changes are a major challenge in biodiversity conservation. KSTs are being re-introduced in the Kihansi gorge after being extinct in the wild. However, linking LULCC in the conservation of the KST is essential to ensure their sustainable existence as more land is needed by local communities for settlement and agriculture. The need for residential areas (settlement) and agricultural land as revealed in this study has a major contribution to the LULCC of forests in the KC and adjacent areas. Continuous LULCC of forest to agricultural land, grazing areas and residential areas (settlements) may result in changes of essential biological and ecological functioning that may not reconcile KST sustainability over time. A study in Mexico revealed a widespread conversion of tropical dry forest to farmland which was accompanied by uncontrolled cattle grazing and fires (Almaza' n-Nu' ñez, et al., 2018). LULCC not only affects the endemic species of amphibians but also other endemic species like birds and reptiles. For instance, a study on endemic bird species distribution in Mexico showed that land-use modifications converted natural habitats to other land use classes of agricultural, industrial, and urban thereby threatening endemic species persistence (Almaza' n-Nú ñ ez, et al., 2018). Similarly Franco-Belussi, et al., (2020) observed that, more natural habitats are being replaced by agricultural areas and settlement (urbanization) leading to decreased amphibian populations and their genomic diversity. In addition, a study on amphibians in Asia showed that forest loss degradation and fragmentation as a result of high deforestation rates have impacted the presence, abundance, diversity, and variability of amphibians (Karraker, et al., 2018). Additionally, human activities and wastes resulted from human settlement closer to riparian vegetation led to decreased amphibians species diversity in Indonesia (Yudha et al., 2019). Furthermore a study by Cordier, et al., (2021) in Argentina showed that, amphibians is among the worldwide most threatened group of vertebrates as a result of land-use changes influenced by agriculture, urbanization, livestock grazing, deforestation and selective logging. The same may occur to KST if measures to rescue and restore the land cover changes that have occurred from 1995- 2020 are not effectively taken.

\subsection{Conclusions And Recommendation}


LULC of KC and adjacent areas were observed to change over years that anticipate threatening the reintroduced KST and their habitat. Agricultural land and settlement increased with time in KC area. The increased agricultural land and settlement lead to decline of forested land in the KC ecosystem. The increase in agricultural land and settlement was promoted by the increase in human population and livestock in villages adjacent the protected areas. This study provides baseline information for land use planning in $\mathrm{KC}$ and adjacent areas that consider sustainable conservation of re-introduced KST while improving the livelihood of local communities adjacent to KC.

\section{Declarations}

\section{Ethics approval and consent to participate}

The ethical clearance was provided by the University of Dodoma for undertaking this study with reference number MA.84/261/02. The participants for the interview were recruited after receiving their informed consent by filling the consent form.

\section{Consent for publication}

Not applicable

\section{Availability of data and materials}

The data and Materials are available at the University of Dodoma, Department of Biology.

\section{Competing interests}

No competing interests exist

\section{Funding}

The funding for this study as accrued from family members as effort to accomplish MSc studies.

\section{Authors' contributions}

Atuhombye Sigala structured and designed the manuscript, Kelvin Ngongolo analyzed the data through statistical,edited manuscript and formatted according to the guideline while Naza Mmbaga Analysed and synthesized the information on Land Use land cover changes

\section{Acknowledgement}

We acknowledge the support rendered by the staffs from the Universuty of Dodoma, Tanzania Widlife research institute for technical advice during project implementation and report writing.

\section{Authors' information (optional)}




\section{References}

1. Almazán-Núñez RC, Sierra-Morales P, Rojas-Soto OR,', nez-Herna' ndez J J., and Mé ndez-Bahena A (2018) Effects of Land-Use Modifications in the Potential Distribution of Endemic Bird Species Associated With Tropical Dry Forest in Guerrero, Southern Mexico. Tropical Conservation Science 11:1-11. https://doi.org/10.1177/1940082918794408

2. Cordier JM, Aguilar R, Lescano JN, Nori J, ... (2021) A global assessment of amphibian and reptile responses to land-use changes. Biol Cons 253(80):108863. DOI:10.1016/j.biocon.2020.108863

3. Franco-Belussi L, Provete DB, Borges RE, De Oliveira C, Santos LRS (2020) Idiosyncratic liver pigment alterations of five frog species in response to contrasting land use patterns in the Brazilian Cerrado. PeerJ 8:e9751. https://doi.org/10.7717/peerj.9751

4. Karraker NE, Fischer S, Aowphol A, Sheridan J, Poo S (2018) Signals of forest degradation in the demography of common Asian amphibians. PeerJ 6:e4220. DOI 10.7717/peerj.4220

5. Kibbassa JAN (2014) Kihansi Catchment Conservation and Management Project. Dar-Es-Salaam

6. Lindenmayer D (2019) Small patches make critical contributions to biodiversity conservation. PNAS 116(3):717-719

7. Mahulu A, Lugelo A, Mtoka S, Ngongolo K (2019) Conservation Education, Alternative Livelihood and Habitat Restoration: The Best Strategies for Conservation of Magombera Forest Reserve. Asian Journal of Environment Ecology 9(4):1-9. https://doi.org/10.9734/ajee/2019/v9i430104

8. Mmbaga N, Munishi L, Treydte A (2017) How dynamics and drivers of land use/land cover change impact elephant conservation and agricultural livelihood development in Rombo, Tanzania. Journal of Land Use Science 12(2):168-181

9. Niesenbaum RA (2019) The Integration of Conservation, Biodiversity, and Sustainability. Sustainability 2019, 11, 4676. Doi: 10.3390/su11174676

10. Ngongolo K, Estes AB, Hudson PJ, Gwakisa PS (2019) Influence of Seasonal Cattle Movement on Prevalence of Trypano - some Infections in Cattle in the Maasai Steppe, Tanzania, 5(3). https://doi.org/10.23937/2474-3658/1510079

11. Rija A, Khatibu F, ., Kohi E, Muheto R (2011) Status and reintroduction of the Kihansi spray toad Nectophrynoides asperginis in Kihansi gorge: challenges and opportunities. In Proceedings of the 7th TAWIRI Scientific Conference (pp. 11-20). Arusha: TAWIRI

12. Thet KK (2014) Pull and Push Factors of Migration. A Case Study in the Urban

13. Area of Monywa Township, Myanmar. Retrieved on 21 (September 2021) from https://www.worldofstatistics.org/files/2014/03/Pull-and-Push-Factors-of-Migration-Thet.pdf

14. Vandvik V, Maren IE, Ndangalasi HJ, Taplin J, Mbago F, Lovett JC (2014) Back to Africa: Monitoring post-hydropower restoration to facilitate reintroduction of an extinct-in-the-wild amphibian.

Ecosphere 5(8):95. https://doi.org/10.1890/ES14-00093.1 
15. Yudha DS, Akmal WR, Eprilurahman R (2019) Monitoring Anurans Diversity along Code River,

Province of Daerah Istimewa Yogyakarta. Indonesia Biogenesis Jurnal Ilmiah Biologi 7(2):132-138. DOI https://doi.org/10.24252/bio.v7i2.10174

\section{Figures}
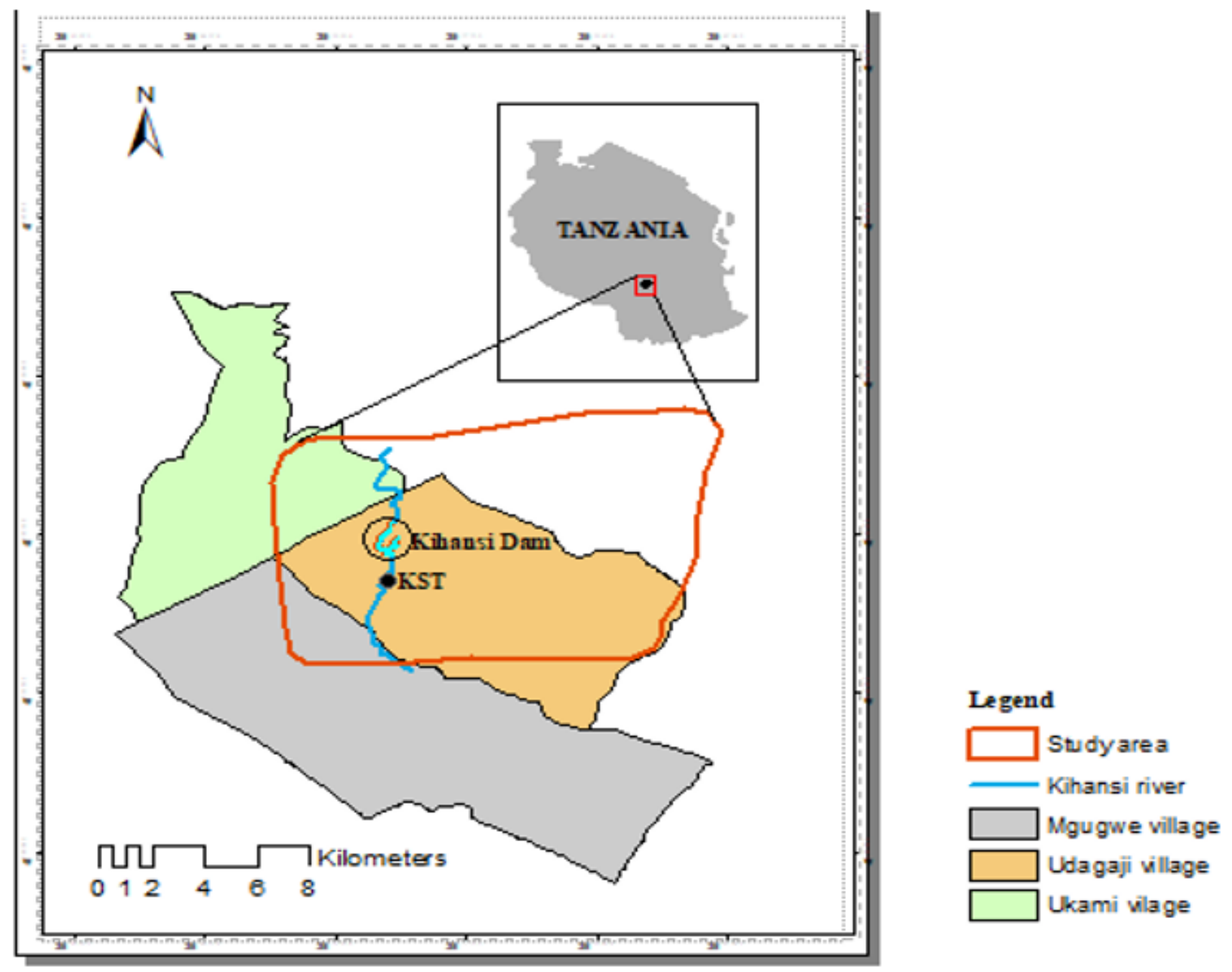

Figure 1

Map showing the study area, in Kihansi catchment and adjacent areas of southern-central Tanzania 


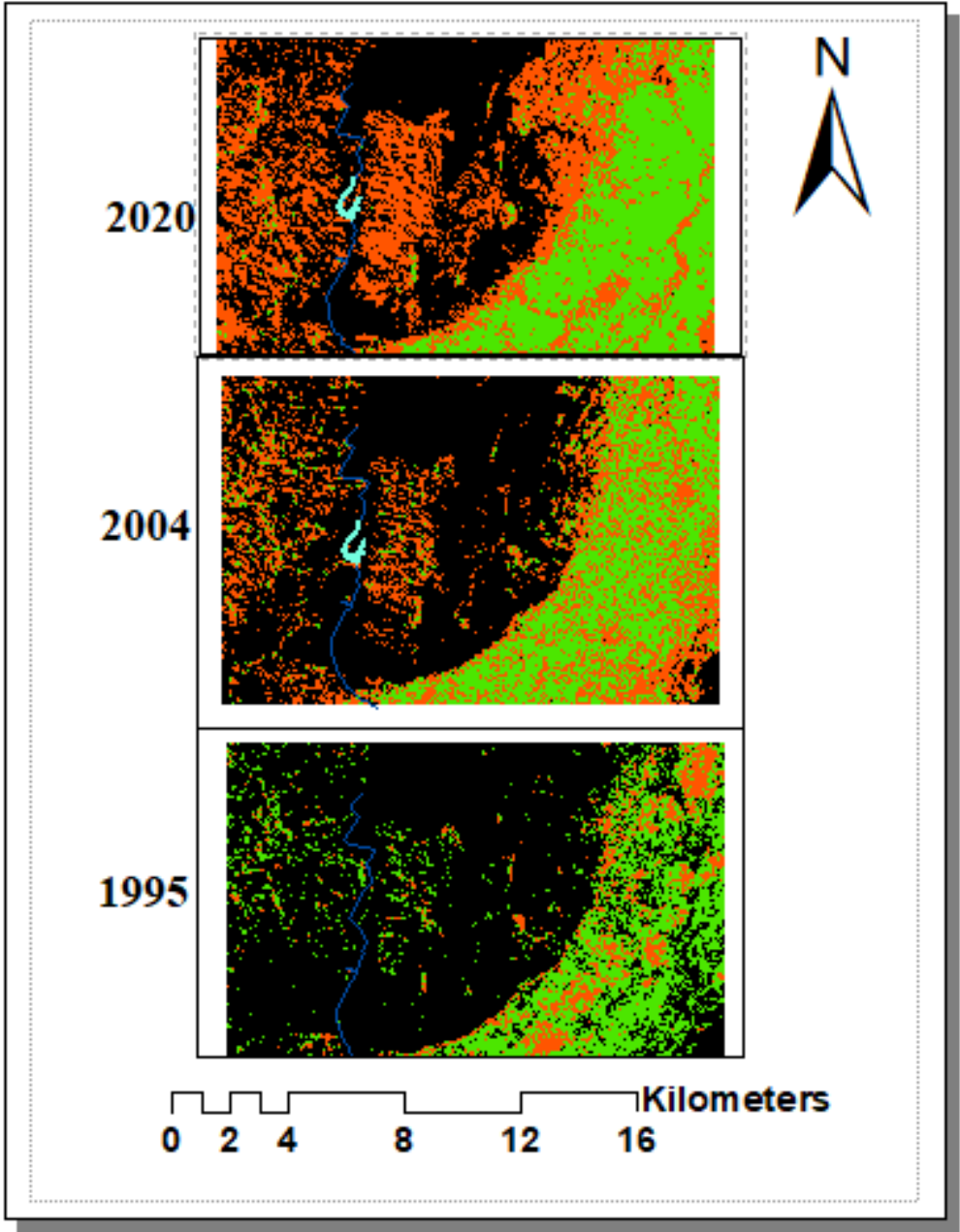

Kihansi dam

Kihansi river

Forested lands

Agricultural lands

Settlem ent

Figure 2

Land use land cover (LULC) types in the years 1995, 2004 and 2020 in Kihansi areas 